\title{
STRUCTURAL REFORMS AND THE ENLARGEMENT OF MONETARY UNION
}

\author{
CARSTEN HEFEKER
}

\author{
CESIFO WORKING PAPER NO. 1057 \\ CATEGory 6: MONETARY POLICY AND INTERNATIONAL FinANCE \\ OCTOBER 2003
}

Presented at Venice Summer Institute, Workshop on Monetary Unions after EMU July 2003

\footnotetext{
An electronic version of the paper may be downloaded

- from the SSRN website:

www.SSRN.com

- from the CESifo website:

www.CESifo.de
} 


\title{
STRUCTURAL REFORMS AND THE ENLARGEMENT OF MONETARY UNION
}

\begin{abstract}
JEL Classification: E61, E63, F33.

Carsten Hefeker

HWWA-Institute of International Economics

Neuer Jungfernstieg 21

20347 Hamburg

Germany

Carsten.Hefeker@hwwa.de
\end{abstract}

The paper addresses the question what effects the enlargement of a monetary union will have on necessary structural reforms in the (low distortion) member countries and the (high distortion) candidate countries. While monetary union lowers reforms in the candidate countries, members of the monetary union will increase their reform efforts. The paper also derives the conditions under which countries agree to an enlargement of monetary union.

Keywords: monetary union, asymmetric shocks, inflation, structural reforms, convergence.

I am grateful to Florin Bilbiie and particpants of the CESifo-Summer Institute on "Monetary Unions after EMU” for helpful and constructive comments. 


\section{Introduction}

After European Monetary Union (EMU) has successfully started with 12 countries, the next major task is its enlargement. While the enlargement of EMU to its EU non-members (Sweden, Denmark and the UK) is unproblematic for the current members, this is less clear for the expected enlargement of the EU to Middle and Eastern European countries. Currently, it seems likely that a group of as many as ten countries will join the EU in a few years time, given that have been accepted as members of the European Union (EU). ${ }^{1}$ The question is whether all of these countries can be considered sufficiently close in economic structure to join monetary union as well. This applies not only to the Maastricht criteria, but to structural features of these countries.

Most of the literature on monetary unification stresses the importance of similarity of economic structures for the success of a monetary union (see e.g. Fidrmuc and Korhonen 2001). But this literature usually takes the economic structure of the countries as given, without taking into account that economic structures change over time (Frankel and Rose 1998). This obviously raises the question when a candidate country might be appropriately reformed to be admitted and willing to join an existing monetary union.

The timing of enlargement has been addressed in a paper by Martin (1995) who, however, takes the convergence of the accession economy as given. He addresses the question when monetary union with low distortions would admit a converging economy. Endogenous structural reforms, in turn, have been analyzed by Ozkan et al. (1997) and Beetsma and Jensen (2003). In those papers, the candidate country must decide if to undertake sufficient reform to be admitted to the union. The candidate country can gain from joining due to the high level of distortions that results in relatively high inflation. Monetary union is a convenient way to solve this problem. By construction, in Beetsma and Jensen (2003) the candidate always wants to join, but the present

${ }^{1}$ Estonia, Poland, Hungary, Cyprus, Slovenia, the Czech Republic, Latvia, Lithuania, Slovak Republic, and Malta are set to join the EU in May 2004. Bulgaria, Romania are still applicants that might join later and with Turkey negotiations have not yet been opened. 
members decide unilaterally about admission. In Ozkan et al. (1997) the candidate has to decide whether to fulfill the entry criteria.

The present paper aims to bring these various aspects together and extends them in several ways. In contrast to the existing literature, it allows for economic distortions in both countries, because it is by no means an unimportant question what impact a possible enlargement will have on the course of economic reforms within the monetary union. Most of the present members of the monetary union need to carry out structural adjustments themselves and the question is whether these are speeded up or slowed down by enlargement. The paper also allows for asymmetric shocks that constitute a potential reason for the candidate country to remain outside the monetary union, even if joining would be possible. Hence, both countries have to agree to enlargement. ${ }^{2}$

In focusing on the economic reforms interacting with the choice of the monetary regime, the present paper also significantly qualifies earlier results concerning the interaction between monetary union and structural reforms. Calmfors (2001), Sibert (1999) and Sibert and Sutherland (2000) have argued that labor market reforms are less likely to be pursued by member countries if they interact with the time-consistency problem. As the latter is automatically reduced by monetary union, there is less incentive for a government to implement structural reforms. This result, however, need not hold in general. By introducing reform needs in the present member states as well, it turns out that monetary union with a high distortion country increases the incentives to implement reforms. Thus, enlargement will lead to more reforms in low distortion countries. This implies that the negative results of monetary union on structural reform efforts derived earlier have to be qualified. It also means that current member states could benefit from an early enlargement of the monetary union.

The paper is structured as follows: The next section presents basic indicators of the state of structural reforms in the accession countries. The following section introduces the model and derives

2 Because even though EMU is an integral part of the acquis communitaire that countries have to accept when entering the EU, it is rather unlikely that countries can be forced to join, as the examples of the UK, Denmark and Sweden show. There is always the possibility deliberately not to fulfill the entry criteria. 
monetary policy decisions in each country (group). Section 4 determines, depending on the monetary regime, the amount of structural reforms in the monetary union and the accession country. Section 5 analyzes under what circumstances the enlargement of the monetary union is possible, and section 6 looks at the alternative of a one sided "hard peg", such as eurozation. Section 7 discusses the limitations of the model and concludes.

\section{The Need for Structural Reforms}

Compared with the situation from which they started, most of the candidate countries for enlargement of the EU (and the EMU) have made considerable progress. ${ }^{3}$ However, as Table 1 and Figure 1 show, in many respects they are still quite a distance away from the European average; most clearly with respect to the inflation and budget deficit criteria (Table 1). More broadly, a summary index of convergence puts all of the candidates listed here at a position well below the EU average, which itself masks considerable differences (Figure 1)

While growth of productivity and GDP are, not surprisingly, higher than in the EU, higher unemployment and larger shares of agriculture and industry in GDP point to the still ongoing process of structural adjustment, which is also evident from a relatively large public sector. In particular, the large share of agriculture in some economies implies large fiscal requirements to subsidize and phase out this sector over time. Large current account deficits and external debt suggest that some of the countries are vulnerable to current account and currency crises. A weak banking system in addition suggests potential problems in the future, because there is a considerable amount of non-performing loans. It is by now well known that some of these indicators reflect the danger of a large scale currency and banking crisis (Tornell 1999). Although tax rates are comparable to Western European ones or even above those (World Bank 2002), the transition economies also regularly manage to

3 This is documented in Fischer et al. (1997), European Commission (2000), Deutsche Bank (2003), World Bank (2002). Continuous monitoring is provided in the EBRD's annual Transition Report. 
acquire significant fiscal deficits (Svejnar 2002). One reason for this could be found in insufficiently effective tax systems and a large underground economy (Burda 1998).

Finally, more qualitative evidence supports the impression that the candidate countries, with a view to the enlargement, are also beginning to introduce labor market regulations and laws that might prove problematic with respect to employment. Many of them are comparable to those in EU countries (Burda 1998, EBRD 2000). The OECD (1999) has put some of the further developed transition economies at a level of labor market regulation even above some of the EU members.

This evidence clearly points to the need of more structural reforms in candidate countries. It is particularly striking that the current situation implies further fiscal needs of governments and these will likely have an influence on monetary policy. The same applies to high unemployment. The higher the structural problems are the more likely it is that these will ultimately lead to an expansive monetary policy.

However distorted the candidate countries might be, there is considerable evidence that the current members have a need for structural reforms themselves. Distortions in the labor market, mainly held responsible for high unemployment in western European countries, and distortions in product markets, like excessive regulation, come to mind (see e.g. Siebert 1997). Thus some of the current members as well need to provide more efforts in labor markets to realize their economic potential. Nevertheless, it still seems that the overall degree of distortions is considerable higher in some of the candidate countries. 
Table 1: Structural Convergence Indicators (2002, estimated)

\begin{tabular}{|c|c|c|c|c|c|c|c|c|c|c|c|}
\hline & EU & Bulgaria & $\begin{array}{l}\text { Czech } \\
\text { Republic }\end{array}$ & Estonia & Hungary & Latvia & Lithuania & Poland & Romania & Slovakia & Slovenia \\
\hline GDP growth & 0.7 & 4.0 & 2.2 & 4.4 & 3.5 & 5.5 & 4.8 & 1.2 & 4.3 & 4.0 & 2.8 \\
\hline Productivity Growth & 0.3 & 5.4 & 4.2 & 4.4 & 3.2 & 6.5 & 7.2 & 4.5 & 5.3 & 3.3 & 2.5 \\
\hline Unemployment & 8.3 & 17.4 & 9.2 & 12.5 & 5.8 & 8.0 & 12.0 & 17.8 & 10.5 & 18.3 & 11.5 \\
\hline Inflation (CPI) & 2.2 & 6.0 & 1.8 & 3.8 & 5.3 & 2.3 & 1.1 & 2.1 & 24.0 & 3.3 & 7.5 \\
\hline Fiscal Balance $(a, c)$ & $-1.5(-3.0)$ & -0.8 & -4.1 & -0.4 & -9.4 & -1.8 & -1.8 & -5.4 & -1.1 & -1.0 & -2.8 \\
\hline $\begin{array}{l}\text { Government Debt (a, } \\
\text { c) }\end{array}$ & $62.5(60.0)$ & 57.3 & 23.3 & 5.1 & 53.3 & 13.9 & 28.4 & 48.0 & 29.2 & 34.5 & 31.0 \\
\hline Cur. Accou. Def. (a) & 0.3 & -5.1 & -5.9 & -7.9 & -5.5 & -8.4 & -5.7 & -4.3 & -4.9 & -7.2 & 0.0 \\
\hline
\end{tabular}

Source: Deutsche Bank (2003), EBRD (1999), Svejnar (2002).

Notes: a) as share of GDP, b) for year 2000, c) data in parenthesis are reference values, d) index by the EBRD. 
Figure 1: Convergence Indicators for Accession Countries

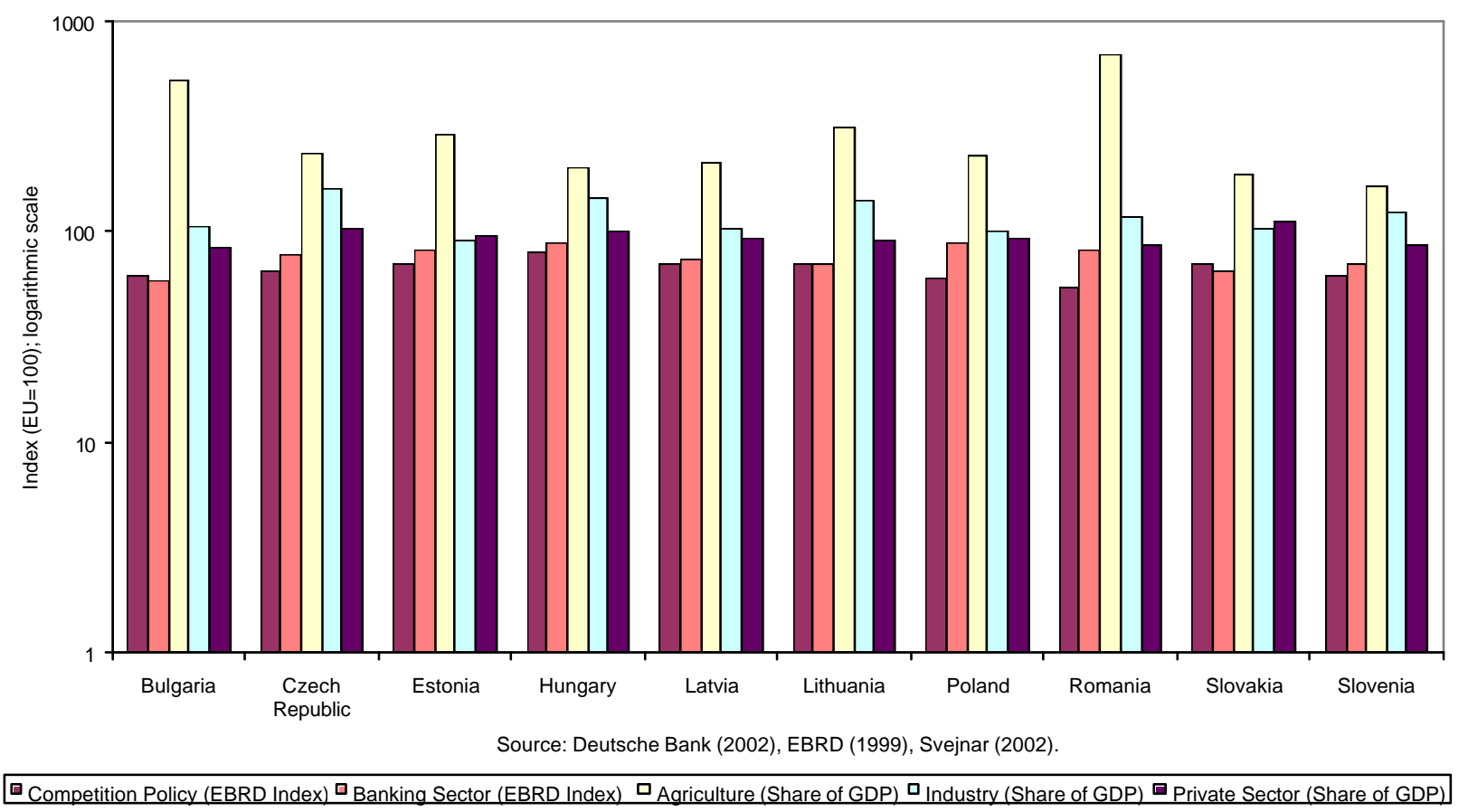

\section{Monetary Policy with and without Monetary Union}

\subsection{The Basic Model}

Consider two countries, one (labelled $\mathrm{H}$ ) where the level of structural distortions is relatively high while the other (L) has relatively low structural distortions. This captures the presence of strong asymmetries between the existing monetary union and the candidates for enlargement that section 2 has demonstrated.

Each country has a government that determines the amount of structural reforms implemented in each period, and a monetary authority that determines the course of monetary policy. Both interact with a private sector that rationally forms expectations about the rate of inflation the central bank will set in response to the economic situation. The timing in each period is as follows: (i) the amount of structural reforms is determined, (ii) inflation expectations are formed, (iii) stochastic shocks may 
occurs, (iv) monetary policy is set, and (v) output is determined. I assume that the governments are Stackelberg-leader vis-a-vis the central banks, but that they play Nash against each other.

It is assumed that structural reforms are time independent, thus distortions in a period are influenced by structural reform in that period (see Beetsma and Jensen 2003). This is not as unrealistic as it might seem at first sight. Unemployment benefits, minimum wages or tax rates are often adjusted by a government on a yearly basis. Moreover, changes in the governing party might involve changes in these areas too. Often, new incoming governments turn back the reforms that the previous government has implemented. This has happened in countries in Eastern Europe and also in countries like Germany or France where, with a change in government, formerly implemented reforms have been taken back (see e.g. Saint-Paul 1996). Moreover, modelling persistent reforms would make no qualitative difference, as discussed in the conclusion.

With these assumptions, output in country $i$ is

$$
\mathrm{y}_{\mathrm{t}}^{\mathrm{i}}=\pi_{\mathrm{t}}^{\mathrm{i}}-\mathrm{E}\left[\pi_{\mathrm{t}}^{\mathrm{i}}\right]-\mathrm{s}_{\mathrm{t}}^{\mathrm{i}}+\xi_{\mathrm{t}}+\varepsilon_{\mathrm{t}}^{\mathrm{i}} \quad \mathrm{i}=\mathrm{L}, \mathrm{H} .
$$

The (log of) potential output is normalized to zero and actual output can be increased through monetary surprises $\pi_{t}^{\mathrm{i}}-\mathrm{E}\left[\pi_{\mathrm{t}}^{\mathrm{i}}\right]$, with $\pi$ denoting inflation and $\mathrm{E}$ the expectations operator. Output is affected by a shock common to the present members countries and to candidate countries $\xi_{t}$, and it is furthermore affected by a country specific exogenous supply shock $\varepsilon_{\mathrm{t}}^{\mathrm{i}}$ that captures the influence of asymmetric business cycle developments. All shocks have an expected value of zero, constant variances, and are uncorrelated. Lastly, $-\mathrm{s}_{\mathrm{t}}^{\mathrm{i}}<0$ denotes the presence of distortions in the economy. As indicated above, this could be due to the presence of strong regulation of employment and production in the economy, a strong presence of government in the economy, or an insufficient 
and distortive tax system. The higher these distortions are the more is the current output below potential output. ${ }^{4}$

Distortions per period are

$$
s_{t}^{i}=k^{i}-c_{t}^{i} \quad \quad i=L, H .
$$

There is a given level of structural distortions $\mathrm{k}^{\mathrm{i}}$ which can, however, be reduced through structural reforms $\mathrm{c}$ in period $t$. Structural reforms are specified very broadly because different countries have different need for particular structural reforms, depending on their economic situation. One might therefore best think about the variable $\mathrm{c}_{\mathrm{t}}^{\mathrm{i}}$ as a vector of policies that can be implemented to reduce distortions in the economy.

Government preferences are given over an infinite horizon but are identical for each period. Per period utility (in logs) for the government is

$$
v_{t}^{i}=-\left\{b\left(y_{t}^{i}\right)^{2}+\left(\pi_{t}^{i}\right)^{2}+\gamma\left(c_{t}^{i}\right)^{2}\right\}+\lambda G^{i} \quad \quad i=L, H .
$$

The government in each country aims to minimize differences between actual and potential output and to minimize deviations of inflation from zero. Structural reforms are (politically) costly because they hurt certain interest groups or voters. Although reforms are output increasing, governments are under pressure from insider labor unions whose members are uncertain about their individual job expectations. Even if aggregate output will increase, individual uncertainty about the consequences of reform can lead to resistance against reform (Fernandez and Rodrik 1991). The more reforms are executed the more potential losers there are and the higher the political costs for the government.

4 With the assumption that purchasing power parities holds there is no influence from trade on output because the real exchange rate is constant. 
Finally, $G^{i}$ is the (political or otherwise) gain for country $i$ from extending monetary union, $\lambda$ is a dummy with $\lambda=1$ when country $H$ enters the union and $\lambda=0$ otherwise. Depending on the relative size of the two countries, one might expect that the larger country has less to gain in political terms than the smaller partner. Moreover, the two countries have probably different political gains to expect from enlargement. Therefore, political gains are country specific.

All other parameters in the utility function are set equal across the countries because I wish to abstract from gains or losses arising through monetary unification that are simply due to differences in preferences (see, e.g., Berger et al. 2001). All governments have the same interest to avoid inflation and are also equally reluctant to implement structural reforms. Hence, all aspects discussed below are due to structural differences between the economies.

\subsection{Monetary Policy before and after Monetary Union}

The central bank has preferences very similar to those of its government, but without being particularly interested in the achievement of monetary union, nor being concerned with the implementation of structural reforms. ${ }^{5}$ Since the central bank has no influence on structural reforms or on the decision of enlargement, these factors have no influence on its optimal policy. Since conflicts between central bank and government in a given country are not focused upon, I set the utility weight parameters equal to those of the government. The period utility of the central bank is

$$
u_{t}^{i}=-\left\{b\left(y_{t}^{i}\right)^{2}+\left(\pi_{t}^{i}\right)^{2}\right\} \quad \text { i=L,H. }
$$

\footnotetext{
5 Actually, one would expect that central banks place a negative value on the achievement of monetary union. Bureaucracy theory at least would suggest that they are interested in maintaining their independence. One might also expect that central banks are in favor of reforms because this reliefs the pressure to reduce unemployment with monetary policy. I abstract from both complications.
} 
Monetary policy is set after the government has decided upon structural reforms and after a possible shock to the output occurred. By assumption, the central bank has full control over the rate of inflation. Taking expected inflation as given and imposing rational expectations, the equilibrium rate of inflation is

$$
\pi_{\mathrm{t}}^{\mathrm{i}}=\mathrm{bs}_{\mathrm{t}}^{\mathrm{i}}-\frac{\mathrm{b}\left(\xi_{\mathrm{t}}+\varepsilon_{\mathrm{t}}^{\mathrm{i}}\right)}{1+\mathrm{b}} \quad \mathrm{i}=\mathrm{L}, \mathrm{H} .
$$

The central bank, if unable to commit to a different policy, will respond to a high degree of structural distortion with an increase of the rate of inflation and will also partly stabilize the shocks $\xi_{\mathrm{t}}$ and $\varepsilon_{\mathrm{t}}^{\mathrm{i}}$. Given rational expectations, the public will expect inflation of this size so that this systematic component of monetary policy has no output effect (Barro and Gordon 1983). Delegating monetary policy to an independent central banker with different preferences would only lead to more output fluctuations (Rogoff 1985). The first best situation could be reached if the government would be able to set distortions to zero. This would also solve the structural inflation problem.

In a monetary union, monetary policy is determined by both formerly separated authorities. The common central bank's per period utility function is assumed to be

$$
u_{t}^{C C}=u_{t}^{L}+\varphi u_{t}^{H}
$$

where the accession country has a weight of $\varphi \leq 1$. It is, however, not very likely that the candidate will receive the same decision power as the current members (Hefeker 2003).

Again, the central bank takes expectations as given when choosing the optimal rate of inflation. With rational expectations it will be

$$
\pi_{t}=\frac{b\left(s_{t}^{\mathrm{L}}+\varphi s_{t}^{\mathrm{H}}\right)}{1+\varphi}-\frac{b \xi_{t}}{(1+b)}-\frac{b\left(\varepsilon_{t}^{\mathrm{L}}+\varphi \varepsilon_{t}^{\mathrm{H}}\right)}{(1+\varphi)(1+b)}
$$


Thus, the common central bank reacts to structural distortions in both countries, where the relative weight $\varphi$ determines by how much developments in the accession country are taken into account.

\section{Structural Reforms under Autonomy and Monetary Union}

The central bank's reaction is taken into account by the government when it determines by how much structural distortion should be reduced. The incentive for the government to reduce structural distortions is twofold. It would increase output directly and it would reduce the central bank's incentive to increase output through inflation. Without the political costs of reform, the government would therefore abolish distortions completely. Because of their costs reforms will be limited.

I begin with monetary autonomy in the two countries. Governments optimize (4) with respect to $\mathrm{c}_{\mathrm{t}}^{\mathrm{i}}$ and subject to (7). This leads to

$$
c_{t}^{i}=\frac{\beta k^{i}}{\gamma+\beta} \quad i=L, H,
$$

with $\beta \equiv b(1+b)>0$. Because distortions are given as $s_{t}^{i}=k^{i}-c_{t}^{i}$, the level of distortions is

$$
s_{t}^{i}=\frac{\gamma k^{i}}{\gamma+\beta} \quad \quad i=L, H .
$$

Structural reforms in the two countries are no longer independent in case of monetary union. Subject to (9), both governments optimize (4) with respect to $c_{t}^{i}$. This yields

$$
c_{t}^{i}=\frac{k^{i}\left[\beta^{i}\left(\gamma+\beta^{j}\right)-\chi^{2}\right]+\gamma \chi k^{j}}{B}, \quad i, j=L, H, i \neq j
$$


with $\beta^{\mathrm{L}} \equiv \mathrm{b}\left(1+\mathrm{b} /(1+\varphi)^{2}\right)>0, \beta^{\mathrm{H}} \equiv \mathrm{b}\left(1+\varphi^{2} \mathrm{~b} /(1+\varphi)^{2}\right)>0, \chi \equiv \varphi b^{2} /(1+\varphi)^{2}>0$, and $\mathrm{B} \equiv\left(\gamma+\beta^{\mathrm{H}}\right)\left(\gamma+\beta^{\mathrm{L}}\right)-\chi^{2}>0$. Notice that $\beta>\beta^{\mathrm{i}}$, and that $\beta^{\mathrm{L}}>\beta^{\mathrm{H}}$ if $\varphi<1$.

This leads to distortions of

$$
\mathrm{s}_{\mathrm{t}}^{\mathrm{i}}=\frac{\gamma}{\mathrm{B}}\left\{\mathrm{k}^{\mathrm{i}}\left(\gamma+\beta^{\mathrm{j}}\right)-\chi \mathrm{k}^{\mathrm{j}}\right\}, \quad \mathrm{i}, \mathrm{j}=\mathrm{L}, \mathrm{H}, \mathrm{i} \neq \mathrm{j}
$$

Equations (10) and (11) show that the introduction of monetary union creates spillovers between the two members. How are economic policy and structural reform in the two countries affected through monetary union? (All proofs are gathered in the Appendix.)

\section{Result 1:}

The extension of monetary union to a high distortion country will induce more reform in the low distortion country and thus reduce distortions if $\mathrm{k}^{\mathrm{H}}$ is sufficiently larger than $\mathrm{k}^{\mathrm{L}}$. The impact on the rate of inflation for country i depends on the difference between $\mathrm{k}^{\mathrm{H}}$ and $\mathrm{k}^{\mathrm{L}}$ and the size of $\varphi$.

\section{Result 2:}

By entering monetary union, structural reform efforts in the high distortion country will fall and distortions will increase. The rate of inflation for the country will fall if its distortions are sufficiently larger than those in the low distortion country.

The intuition for these results is straightforward. Because the low distortion country is inflation averse it wants to avoid that high distortions in the new member country increase common inflation. To lower the incentives for the common central bank to increase inflation, distortions will be further reduced. Therefore, extension of the monetary union leads to even more structural reforms in low distortion country. This result reverses that by Calmfors (2000) and Sibert and Sutherland (2000) 
who assumed that one country exhibits no distortions. Only in that case can symmetric countries export part of the inflationary consequences of distortions, which leads them to roll back structural reforms after monetary union. If, instead, some asymmetric countries import inflationary pressure they will increase structural reforms to counter this effect. In that case enlargement has positive output and employment effects.

The influence of enlargement on inflation is not certain because there are two conflicting influences on the central bank. On the one hand, the inclusion of the high distortion country increases inflationary pressure. On the other hand, more structural reforms in the other country reduce this pressure. The net effect is thus ambiguous depending on the relative influence of the high distortion country on common monetary policy. Only if that is sufficiently large will inflation in current member states increase. Otherwise, inflation may even be lower than before.

The result for the high distortion country follows the reverse logic of the above argument. Because for that country inflation is automatically reduced when entering monetary union, incentives for the government to reduce the structural distortions in the economy fall. At the same time, the rate of inflation will decrease because the common central bank cares less for developments in any single country and because the increased reform efforts in the other member country additionally reduce pressure on the common central bank.

The strength of these results depends on the relative weight of the high-distortion country $\varphi$. If the new members have a decision weight of close to zero they do not influence the common monetary policy and therefore the spillover effects on the current members are zero. ${ }^{6}$ The question of relative weight will therefore be of great policy importance and probably trigger a debate about the appropriate voting weight of accession countries (see Berger 2002, Hefeker 2003).

\section{Enlargement of the Monetary Union}

\subsection{The Governments' Position towards Enlargement}

${ }^{6}$ For the effect on the candidate countries in this case, see the section on euroization below. 
I next turn to the question under what conditions it would be optimal for the low distortion country to admit the other country to the monetary union? To keep matters simple, I restrict the considerations of shocks to asymmetric shocks to one country only and set $\xi_{\mathrm{t}}=0, \varepsilon_{\mathrm{t}}^{\mathrm{L}}=0$, $\varepsilon_{t}^{H}=\varepsilon_{t}$ in what follows. For the present purpose, it only matters by how much the optimal response to economic shocks is compromised through monetary union. If shocks are identical, monetary union does not distort the optimal response for individual countries. Problems only arise if asymmetric shocks occur.

The positive effects from monetary union for the low distortion country are the political gains from monetary union and the reduction of structural distortions. While this is clearly beneficial from an economic point of view, the government will still oppose more reforms because they are politically costly. To be able to confirm that there is an incentive for this country to allow enlargement of the monetary union, it is necessary to show that there are cases in which the government nevertheless profits from the enlargement of monetary union.

Government utility under monetary autonomy (A) can be computed from using (5) and (9) in (1) and (1), (5), (8) in (3). That under monetary unification (MU) follows from (7) and (11) in (1), and (1), (7) and (10) in (3). Comparing the utility levels, one has to concentrate on expected values because of the stochastic shock. The condition for $E\left[u_{t}^{L}(M U)\right]>E\left[u_{t}^{L}(A)\right]$ is

$$
\begin{aligned}
& b\left[\left(s_{t}^{\mathrm{L}}(\mathrm{A})\right)^{2}-\left(\mathrm{s}_{\mathrm{t}}^{\mathrm{L}}(\mathrm{MU})\right)^{2}\right]+\mathrm{G}^{\mathrm{L}}> \mathrm{b}^{2}\left[\frac{\left(\mathrm{s}_{\mathrm{t}}^{\mathrm{L}}(\mathrm{MU})+\varphi s_{\mathrm{t}}^{\mathrm{H}}(\mathrm{MU})\right)^{2}}{(1+\varphi)^{2}}-\left(\mathrm{s}_{\mathrm{t}}^{\mathrm{L}}(\mathrm{A})\right)^{2}\right] \\
&+\gamma\left[\left(\mathrm{c}_{\mathrm{t}}^{\mathrm{L}}(\mathrm{MU})\right)^{2}-\left(\mathrm{c}_{\mathrm{t}}^{\mathrm{L}}(\mathrm{A})\right)^{2}\right]+\frac{\mathrm{b}^{2} \varphi^{2} \sigma^{2}}{(1+\mathrm{b})(1+\varphi)^{2}}
\end{aligned}
$$

with $\sigma^{2}=\mathrm{E}\left[\varepsilon_{\mathrm{t}}^{2}\right]$. The interpretation of this condition is straightforward. On the left side, expressing the gains from enlarging monetary union, are the political gain $\mathrm{G}^{\mathrm{L}}$ and the positive effects from more structural reforms on output. On the right side the costs of monetary union are collected. The first term expresses the potential increase in inflation that is due to the fact that the common central bank 
will take care of the structural distortion in the new member country. Whether the expression is overall positive depends on the size of the distortion in that country and by how much this influences the monetary policy of the common central bank. Because $s_{t}^{\mathrm{L}}(\mathrm{MU})<\mathrm{s}_{\mathrm{t}}^{\mathrm{L}}(\mathrm{A})$, it is however possible that this term is negative, thus reducing the negative effects from enlargement (cf. Result 1). The second term compares this with the central bank reaction under autonomy. The third term on the right side denotes the government's aversion to higher structural reforms, due to the political costs that it suffers when implementing more reforms. Finally, the last term expresses the losses from higher variance due to the shocks to the accession country.

By the same logic, one can compare utility under autonomy and monetary union for $\mathrm{H}$. The condition for $E\left[u_{t}^{H}(M U)\right]>E\left[u_{t}^{H}(A)\right]$ is

$$
\begin{gathered}
\mathrm{b}^{2}\left[\left(\mathrm{~s}_{\mathrm{t}}^{\mathrm{H}}(\mathrm{A})\right)^{2}-\frac{\left(\mathrm{s}_{\mathrm{t}}^{\mathrm{L}}(\mathrm{MU})+\varphi \mathrm{s}_{\mathrm{t}}^{\mathrm{H}}(\mathrm{MU})\right)^{2}}{(1+\varphi)^{2}}\right]+\gamma\left[\mathrm{c}_{\mathrm{t}}^{\mathrm{H}}(\mathrm{A})^{2}-\mathrm{c}_{\mathrm{t}}^{\mathrm{H}}(\mathrm{MU})^{2}\right]+\mathrm{G}^{\mathrm{H}}> \\
\left.\frac{\mathrm{b}^{2} \sigma^{2}}{(1+\mathrm{b})(1+\varphi)^{2}}+\mathrm{b} \mid \mathrm{s}_{\mathrm{t}}^{\mathrm{H}}(\mathrm{MU})^{2}-\mathrm{s}_{\mathrm{t}}^{\mathrm{H}}(\mathrm{A})^{2}\right] .
\end{gathered}
$$

The high distortion country profits from monetary union because the inflationary response to distortions in the economy is lower under monetary union (measured in the first two terms on the left side). The government also profits because structural reforms are lower and therefore lower political costs arise (third term on the left side), and because it may realize political gains from the union. Costs that are connected with monetary union arise from the fact that the idiosyncratic shock is not stabilized as much as under autonomy and that higher distortions under the monetary union lead to lower output (measured on the right side). 


\subsection{How Likely is Extension?}

The interest of the low distortion country in enlargement is that is might increase output through the reduction of distortions. If the country, however, is very reform averse, it will probably resist enlargement. In contrast, a strong interest in output increases are beneficial for its consent to enlargement. Trivially, the country's willingness to admit a new member to the monetary union is increasing in the political gain. It also obvious that the idiosyncratic shock, that implies more variance in inflation and employment, is negative from that country's point of view. The low distortion country, however, gains from extension of monetary union if the new member's distortions are high. Defining a function $\omega_{t}^{i}$ that measures the gains from monetary union: $E\left[\omega_{t}^{i}\right]=E\left[v_{t}^{i}(M U)\right]-E\left[v_{t}^{i}(A)\right]$, it follows that $\partial \mathrm{E}\left[\omega_{\mathrm{t}}^{\mathrm{L}}\right] / \partial \mathrm{k}^{\mathrm{H}}=\mathrm{k}^{\mathrm{L}}\left[\left(\gamma+\beta^{\mathrm{H}}\right)\left(\beta^{\mathrm{L}}-\mathrm{b}\right)+(\gamma+\mathrm{b})^{2}-\chi\right]+\mathrm{k}^{\mathrm{H}}(\gamma+\mathrm{b})[\varphi(\gamma+\mathrm{b})+\chi]>0$. This is because the central bank's reaction to these distortions induces more reforms in the low distortion country which will therefore be able to increase its output.

The candidate country benefits mainly because it can relax its reform efforts. This implies that a strong resistance against reforms would suggest enlargement. Contrary to what might be expected it follows that reform averse governments actually benefit from enlargement once they inside the union. The candidate also benefits since the structural component of inflation falls; thus a strong inflation aversion is beneficial for enlargement. Again, it is obvious that political gains make enlargement more attractive for the government. But since monetary union implies that common monetary policy will address the idiosyncratic shocks to the country, monetary union is less attractive if these shocks exhibit a high variance (cf. eq. 13 ). Moreover, even the high distortion country is affected by distortions in the current member states because $\partial \mathrm{E}\left[\omega_{\mathrm{t}}^{\mathrm{H}}\right] / \partial \mathrm{k}^{\mathrm{L}}=$ $\left.\mathrm{k}^{\mathrm{H}} \mid\left(\gamma+\beta^{\mathrm{L}}\right)\left(\beta^{\mathrm{H}}-\mathrm{b}\right)+\varphi(\gamma+\mathrm{b})^{2}-\chi^{2}\right\rfloor-\mathrm{k}^{\mathrm{L}}(\gamma+\mathrm{b})[(\gamma+\mathrm{b})-\chi]$. This expression is only positive if the distortions $\mathrm{k}^{\mathrm{H}}$ are sufficiently larger than $\mathrm{k}^{\mathrm{L}}$. The accession country will thus lose interest in monetary union the higher the distortions in the low distortion country are. Because a high value of $s_{t}^{L}$ implies a relatively high rate of inflation, the country could gain less in terms of lower inflation from entering the union. In addition, the level of reforms would not fall by much. 
Both countries are hence most likely to agree to the enlargement if idiosyncratic shocks are not too large and if the distortions in both countries are not above a critical level. It is further supported if both partners expect large political gains. Since extension brings for both of them positive and negative effects, it is important how large the relative influence of these effects is on utility. Because the effects of EMU on distortions, output and inflation have opposite signs for the two countries, an extension would be agreeable for both if the preference parameters that measure the influence of these effects on utility have intermediate values. ${ }^{7}$ Countries that are predominantly focused on inflation, output or strucutral reforms are likely to resist enlargement more than countries that value positive and negative effects of enlargement more equally.

\section{Eurozation}

An alternative to full monetary union that has been adopted recently by some countries is a socalled "hard peg" in which one country ties its monetary policy credibly to that of another country, thereby reducing its inflation. Such hard pegs could be in the form of a currency board or the introduction of the anchor curreny as a means of payment. Examples for either regime can be found in Latin America (Argentina operated a currency board until recently, while Ecuador and Puerto Rico are dollarized), Asia (Hong Kong's currency board), and Eastern Europe (in the former category are Bulgaria and Estonia, in the latter category is Montenegro).

The benefits of such a regime in form of more credibility and a lower probability of speculative attacks have to be weighed against the forgone possibility to use monetary policy to account for shocks and the loss of a lender-of-last resort. ${ }^{8}$ For some of the likely candidates for enlargement of EU and EMU, it has been argued that the benefits of full eurozation would clearly dominate the costs

${ }^{7}$ Note that the model supposes equal preference parameters. If they differ between the countries, it might be easier to find support for enlargement.

8 See, however, Calvo (1999) who argues that this need not be true. There are ways to retain the possibility of a lender-of-last resort. 
(Gros 2000). ${ }^{9}$ Thus, the present section analyzes the effects of such a eurozation on countries considering to join such an arrangement. I will only consider the case of a full eurozation because it is more credible than a currency board (as Argentina has recently demonstrated) and thus directly comparable to monetary union. In this case, the situation for the low distortion country is the same as under monetary autonomy.

The rate of inflation for the pegging country is then

$$
\pi_{t}^{\mathrm{H}}=\mathrm{bs}_{\mathrm{t}}^{\mathrm{L}}=\frac{\mathrm{b} \gamma \mathrm{k}^{\mathrm{L}}}{\gamma+\beta} .
$$

The strategic decision of setting structural reforms would now be different because the rate of inflation is exogenous for the government, thus making it no longer the Stackelberg leader in its relation with the central bank. Hence, the government optimizes (3) with respect to $c_{t}^{H}$, subject to (1) and (14). This leads to

$$
c_{t}^{\mathrm{H}}=\frac{b^{\mathrm{H}}}{\gamma+b},
$$

and a level of distortions of

$$
\mathrm{s}_{\mathrm{t}}^{\mathrm{H}}=\frac{\gamma \mathrm{k}^{\mathrm{H}}}{\gamma+\mathrm{b}} .
$$

How do these results compare to monetary autonomy and full membership in the monetary union?

${ }^{9}$ Euroization is, however, legally not compatible with the Maastricht treaty since it precludes that conversion rates be set by the Council of Ministers. For ways around this problem, see Buiter and Grafe (2002). 


\section{Result 3:}

Compared with monetary autonomy, under eurozation reforms efforts will fall and distortions will increase in the high distortion country. Inflation will be lower than under monetary autonomy. Distortions increase even more than under full membership in the monetary union.

The logic for this result is the following. Inflation will fall when monetary policy is tied to the low distortions country; this implies that structural reform efforts fall. They fall even more than under the monetary union because in this case the government has no influence on the rate of inflation, and therefore no incentive to keep inflation low by implementing reforms.

When deciding whether full membership or eurozation is preferable, the government has to weigh several effects. The benefit of eurozation is that it brings an even lower rate of inflation and even less structural reforms, which is politically attractive. The costs of this regime are higher, however, because output will fall and because there are no political gains from entering a union and exogenous shock are no longer stabilized.

Formally, the condition for $\mathrm{E}\left[\mathrm{u}_{\mathrm{t}}^{\mathrm{H}}(\mathrm{E})\right]>\mathrm{E}\left[\mathrm{u}_{\mathrm{t}}^{\mathrm{H}}(\mathrm{MU})\right]$, where $\mathrm{E}$ stand for eurozation, is

$$
\begin{gathered}
b^{2}\left[\frac{\left(s_{t}^{\mathrm{L}}(M U)+\varphi s_{t}^{\mathrm{H}}(M U)\right)^{2}}{(1+\varphi)^{2}}-\left(s_{t}^{\mathrm{L}}(\mathrm{A})\right)^{2}\right]+\gamma\left[\mathrm{c}_{\mathrm{t}}^{\mathrm{H}}(\mathrm{MU})^{2}-\mathrm{c}_{\mathrm{t}}^{\mathrm{H}}(\mathrm{E})^{2}\right]> \\
\mathrm{b}\left[\mathrm{s}_{\mathrm{t}}^{\mathrm{H}}(\mathrm{E})^{2}-\mathrm{s}_{\mathrm{t}}^{\mathrm{H}}(\mathrm{MU})^{2}\right]-\mathrm{b} \sigma^{2}\left\{\left(1-\frac{\varphi b}{(1+\mathrm{b})(1+\varphi)}\right)^{2}-1\right\}+\mathrm{G}^{\mathrm{H}} .
\end{gathered}
$$

The condition states that euroization is preferable if the government is averse to inflation and to structural reforms. Unless it has a strong aversion against structural reforms and inflation, however, it is clearly worse off under eurozation, because distortions and output variability increase. In addition, it forgoes the political gains from full membership. 
This is obviously different for the anchor country that has to bear no costs at all under such a regime. Nevertheless, full membership of the high distortion country would be better for the low distortion country in as much output would increase due to more structural reforms. Depending on the relative weight of output and aversion to reforms, it could then be that full membership is preferable for both countries.

\section{Conclusion}

The paper derived the influence of an extension of monetary union on the structural features in accession countries and on current members. One could expect that the extension of monetary union would result in more structural reforms being undertaken within the current member states. In this respect, an early extension of EMU to the Middle and Central European countries would be desirable in terms of necessary structural reforms and add to the expected gains from trade integration (see Baldwin et al. 1997 on these gains). As the governments oppose politically costly structural reforms, this result can be one explanation why the extension of the EU is made conditional on convergence of the candidates to the member states. Only then an extension will have little influence on developments in the current member states. This might also be one reason why current members are eager to restrict the influence of accession countries.

By contrast, extension will most likely result in a slowing down of reform efforts in the joining countries. But regardless of this being the case, these countries are very likely to gain from extension in terms of lower inflation. It is also clear that the gains for these countries from joining are the largest as long as the structural distortions are high. Then the gains in credibility and reduction in inflation will more than outweigh the negative output consequences of a slowdown in economic reforms. In addition, political gains are presumably larger in the beginning than later on. Only if the negative effect from idiosyncratic shocks is very high, non accession seems more attractive.

These results, stemming from the model applied, may look somewhat counter intuitive initially. But the logic of the model is more relevant than first impression might suggest. The main logic that the model captures is a relation between structural distortions and monetary policy, and that weak 
financial and fiscal systems tend to have higher inflation in order to support fiscal budgets. Labor market distortions and high unemployment as well exert pressure on monetary policy that might simply be due to the fact that distorted labor market are less able to cope with shocks, thus requiring more stabilizing monetary policy. Moreover, the model captures the salient feature of the Maastricht treaty and the entrance criteria to the EMU that suppose a relation between monetary policy and structural policies. Otherwise there would be no need for such criteria.

Nevertheless, this is a highly stylized model neglecting some important additional influences on output such as fiscal policy. For instance, allowing for persistent reforms would mitigate some of the results as distortions in both countries would decline over time. The speed of reform would decline or accelerate respectively with enlargement, however. The influence derived here would thus still apply to further reform efforts.

One possible conclusion from the analysis, that is in contrast to the official EU position, is that an early extension of monetary union could bring benefits for both groups of countries. Only a full monetary union brings benefits to the current members in terms of more structural reforms.

\section{Appendix:}

Proof of Result 1: Since the amount of initial distortions is not affected by monetary union, reforms will directly reduce distortions. Comparing (11) and (13) shows that the condition for distortions in county $i$ to be reduced, $s_{t}^{\mathrm{L}}(\mathrm{A})>\mathrm{s}_{\mathrm{t}}^{\mathrm{L}}(\mathrm{MU})$, where A and MU denote the case of monetary autonomy and monetary union respectively, is $\mathrm{k}^{\mathrm{H}}>\mathrm{k}^{\mathrm{L}} \frac{\left(\gamma+\beta^{\mathrm{H}}\right)\left(\beta-\beta^{\mathrm{L}}\right)+\chi^{2}}{\chi(\gamma+\beta)}$. Although $\mathrm{k}^{\mathrm{H}}>\mathrm{k}^{\mathrm{L}}$, the multiplier on the RHS is larger than one, because $\left(\gamma+\beta^{\mathrm{H}}\right)\left(\beta-\beta^{\mathrm{L}}\right)+\chi^{2}>\chi(\gamma+\beta)$ can be rewritten as $(\gamma+b)(1+\varphi)-\frac{b^{2}\left(1-\varphi^{2}\right)}{1+\varphi}>0$. This is clearly fulfilled for $b<1$ (or if $\varphi=1$ ).

Likewise, the comparison of inflation before and after monetary unification, yields that $\pi_{\mathrm{t}}^{\mathrm{L}}(\mathrm{MU})>\pi_{\mathrm{t}}^{\mathrm{L}}(\mathrm{A})$ if $\varphi \mathrm{k}^{\mathrm{H}}>\mathrm{k}^{\mathrm{L}}\left[\frac{(1+\varphi) \mathrm{B}}{(\gamma+\beta)(\gamma+\mathrm{b})}-1\right]$. The multiplier is positive for $\mathrm{b}<1$, but smaller 
than one if $(\gamma+b)\left[1-b-\varphi^{2}\left(1+b^{2}\right)\right]+2 b^{2}(1+\varphi)>0$. Hence, depending on the difference between $\mathrm{k}^{\mathrm{H}}$ and $\mathrm{k}^{\mathrm{L}}$ and the size of $\varphi$, inflation may increase or decrease.

Proof of Result 2: The condition for $s_{t}^{H}(M U)>s_{t}^{H}(A)$ is $k^{H} \frac{\left(\gamma+\beta^{L}\right)\left(\beta-\beta^{H}\right)+\chi^{2}}{\chi(\gamma+\beta)}>k^{L}$. Since $\mathrm{k}^{\mathrm{H}}>\mathrm{k}^{\mathrm{L}}$ and because the multiplier on the LHS is larger than one, this condition is fulfilled.

The comparison of inflation before and after monetary unification for country $\mathrm{H}$ yields that $\pi_{\mathrm{t}}^{\mathrm{H}}(\mathrm{A})>\pi_{\mathrm{t}}^{\mathrm{H}}(\mathrm{MU})$ if $\mathrm{k}^{\mathrm{H}}\left[\frac{(1+\varphi) \mathrm{B}}{(\gamma+\beta)(\gamma+\mathrm{b})}-\varphi\right]>\mathrm{k}^{\mathrm{L}}$. The multplier on $\mathrm{k}^{\mathrm{H}}$ is positive but not necessarily larger than one. The inflationary situation in country $\mathrm{H}$ will improve if $\mathrm{k}^{\mathrm{H}}$ is sufficiently larger than $\mathrm{k}^{\mathrm{L}}$.

\section{Proof of Result 3:}

Follows from a direct comparison of (9) with (16) and of (5) with (14) respectively. The condition that $s_{t}^{\mathrm{H}}(\mathrm{E})>\mathrm{s}_{\mathrm{t}}^{\mathrm{H}}(\mathrm{MU})$ is $\mathrm{k}^{\mathrm{H}}\left\lfloor\left(\gamma+\beta^{\mathrm{L}}\right)\left(\beta^{\mathrm{H}}-\mathrm{b}\right)-\chi^{2}\right\rfloor+\mathrm{k}^{\mathrm{L}} \chi(\gamma+\mathrm{b})>0$ which is fulfilled.

\section{References}

Baldwin, R. E., J. P. Francois and R. Portes (1997) The Costs and Benefits of Eastern Enlargement: The Impact on the EU and Central Europe, Economic Policy 24, 125-176.

Barro, R. and D. Gordon (1983) A Positive Theory of Monetary Policy in a Natural Rate Model, Journal of Political Economy 91, 589-610.

Beetsma, R. and H. Jensen (2003) Structural Convergence under Reversible and Irreversible Monetary Unification, Journal of International Money and Finance 22, 417-439.

Berger, H. (2002) The ECB and Euro-Area Enlargement, IMF Working Paper 02/175.

Berger, H., H. Jensen and G. Schjelderup (2001) To Peg or Not to Peg? A Simple Model of Exchange Rate Regime Choice in Small Economies, Economics Letters 73, 161-167.

Buiter, W. H. and C. Grafe (2002) Anchor, Float or Abandon Ship: Exchange Rate Regimes for the Accession Countries, Banca Nazionale Lavoro Quarterly Review, No. 221, 1-32. 
Burda, M. (1998) The Consequences of EU Enlargement for Central and Eastern European Labor Markets, EIB Papers 3, 65-82.

Calmfors, L. (2001) Labor Market Reform and Monetary Union, Journal of Labor Economics 19, 265-289.

Calvo, G. (1999) On Dollarization, University of Maryland, mimeo.

Deutsche Bank Research (2003) EU Enlargement Monitor No. 10, January, Frankfurt: Deutsche Bank.

EBRD (European Bank for Reconstruction and Development) (1999) Transition Report, London: EBRD.

European Commission (2000) Enlargement Strategy Paper, Brussels: EU-Commission.

Fernandez, R. and D. Rodrik (1991) Resistance to Reform: Status Quo Bias in the Presence of Individual-Specific Uncertainty, American Economic Review 81, 1146-1155.

Fidrmuc, J. and I. Korhonen (2001) Similarity of Supply and Demand Shocks Between the Euro Area and the CEEs, Bank of Finland, BOFIT Discussion Paper 2001/14.

Fischer, S., R. Sahay, C. A. Végh (1997) How Far is Eastern Europe from Brussels?, in H. Siebert, ed: Quo Vadis Europe?, Tübingen: Mohr (Siebeck), 97-122.

Frankel, J. A. and A. K. Rose (1998) The Endogeneity of the Optimum Currency Area Criterion, Economic Journal 108, 1009-1025.

Gros, D. (2000) One Euro from the Atlantic to the Urals? CESifo Forum 2, 26-31, Munich: CESifo.

Hefeker, C. (2003) Federal Monetary Policy, Scandinavian Journal of Economics, forthcoming.

Martin, P. (1995) Free-Riding, Convergence and Two-Speed Monetary Unification in Europe, European Economic Review 39, 1345-1364.

OECD (Organisation for Economic Co-operation and Development) (1999) Employment Outlook, Paris: OECD.

Ozkan, F. G., A. Sibert and A. Sutherland (1997) Monetary Union, Entry Conditions and Economic Reform, CEPR Discussion Paper 1720. 
Rogoff, K. (1985) The Optimal Degree of Commitment to an Intermediate Monetary Target, Quarterly Journal of Economics 100, 1169-1190.

Saint-Paul, G. (1996) Exploring the Political Economy of Labour Market Institutions, Economic Policy 23, 263-315.

Sibert, A. (1999) Monetary Integration and Economic Reform, Economic Journal 109, 78-92.

Sibert, A. and A. Sutherland (2000) Monetary Regimes and Labour Market Reform, Journal of International Economics 51, 421-435.

Siebert, H. (1997) Labor Market Rigidities: At the Root of Unemployment in Europe, Journal of Economic Perspectives 11 (Summer), 37-54.

Svejnar, J. (2002) Transition Economies: Performance and Challenges, Journal of Economic Perspectives 18 (Winter), 3-28.

Tornell, A. (1999) Common Fundamentals in the Tequila and Asian Crises, NBER Working Paper 7139.

World Bank (2002) Transition: The First Ten Years, Washington D.C.: World Bank. 


\section{CESifo Working Paper Series}

(for full list see www.cesifo.de)

994 Louis N. Christofides and Chen Peng, Contract Duration and Indexation in a Period of Real and Nominal Uncertainty, July 2003

995 M. Hashem Pesaran, Til Schuermann, Björn-Jakob Treutler, and Scott M. Weiner, Macroeconomic Dynamics and Credit Risk: A Global Perspective, July 2003

996 Massimo Bordignon and Sandro Brusco, On Enhanced Cooperation, July 2003

997 David F. Bradford, Addressing the Transfer-Pricing Problem in an Origin-Basis X Tax, July 2003

998 Daniel Gros, Who Needs Foreign Banks?, July 2003

999 Wolfram Merzyn and Heinrich W. Ursprung, Voter Support for Privatizing Education: Evidence on Self-Interest and Ideology, July 2003

1000 Jo Thori Lind, Fractionalization and the Size of Government, July 2003

1001 Daniel Friedman and Donald Wittman, Litigation with Symmetric Bargaining and TwoSided Incomplete Information, July 2003

1002 Matthew Clarke and Sardar M. N. Islam, Health Adjusted GDP (HAGDP) Measures of the Relationship Between Economic Growth, Health Outcomes and Social Welfare, July 2003

1003 Volker Grossmann, Contest for Attention in a Quality-Ladder Model of Endogenous Growth, August 2003

1004 Marcel Gérard and Joan Martens Weiner, Cross-Border Loss Offset and Formulary Apportionment: How do they affect multijurisdictional firm investment spending and interjurisdictional tax competition?, August 2003

1005 Burkhard Heer, Nonsuperneutrality of Money in the Sidrauski Model with Heterogeous Agents, August 2003

1006 V. Anton Muscatelli, Piergiovanna Natale, and Patrizio Tirelli, A Simple and Flexible Alternative to the Stability and Growth Pact Deficit Ceilings. Is it at hand?, August 2003

1007 Reto Foellmi and Josef Zweimüller, Inequality and Economic Growth: European Versus U.S. Experiences, August 2003

1008 James S. Costain and Michael Reiter, Business Cycles, Unemployment Insurance, and the Calibration of Matching Models, August 2003 
1009 Marco Runkel, Optimal Contest Design when the Designer's Payoff Depends on Competitive Balance, August 2003

1010 Donald O. Parsons, Torben Tranaes and Helene Bie Lilleør, Voluntary Public Unemployment Insurance, August 2003

1011 Rüdiger Pethig and Andreas Wagener, Profit Tax Competition and Formula Apportionment, August 2003

1012 Johan Willner, Privatisation and Public Ownership in Finland, August 2003

1013 Seppo Kari and Jouko Ylä-Liedenpohja, Taxation and Valuation of International Real Investments, August 2003

1014 James Heckman, Rosa Matzkin and Lars Nesheim, Simulation and Estimation of Hedonic Models, August 2003

1015 Biswa N. Bhattacharyay, Towards a Macro-Prudential Leading Indicators Framework for Monitoring Financial Vulnerability, August 2003

1016 J. Stephen Ferris and Stanley L. Winer, Searching for Keynes: With Application to Canada, 1870-2000, August 2003

1017 Massimo Bordignon, Luca Colombo and Umberto Galmarini, Fiscal Federalism and Endogenous Lobbies' Formation, August 2003

1018 Annette Alstadsæter, The Dual Income Tax and Firms' Income Shifting through the Choice of Organizational Form and Real Capital Investments, August 2003

1019 Peter Fredriksson and Bertil Holmlund, Optimal Unemployment Insurance Design: Time Limits, Monitoring, or Workfare?, August 2003

1020 Kashif S. Mansori, Following in their Footsteps: Comparing Interest Parity Conditions in Central European Economies to the Euro Countries, August 2003

1021 Christoph Borgmann and Matthias Heidler, Demographics and Volatile Social Security Wealth: Political Risks of Benefit Rule Changes in Germany, August 2003

1022 Kjell Erik Lommerud, Bjørn Sandvik and Odd Rune Staume, Good Jobs, Bad Jobs and Redistribution, August 2003

1023 Patrick Karl O'Brien, The Governance of Globalization: The Political Economy of Anglo-American Hegemony, 1793-2003, September 2003

1024 Antonio Ciccone and Giovanni Peri, Skills' Substitutability and Technological Progress: U.S. States 1950-1990, September 2003

1025 Bjørn Sandvik, Optimal Taxation and Normalisations, September 2003 
1026 Massimo Bordignon and Gilberto Turati, Bailing Out Expectations and Health Expenditure in Italy, September 2003

1027 José A. Herce, Namkee Ahn, Ricard Génova, and Joaquín Pereira, Bio-Demographic and Health Aspects of Ageing in the EU, September 2003

1028 John Komlos and Marieluise Baur, From the Tallest to (One of) the Fattest: The Enigmatic Fate of the American Population in the $20^{\text {th }}$ Century, September 2003

1029 Stefan Napel and Mika Widgrén, Bargaining and Distribution of Power in the EU's Conciliation Committee, September 2003

1030 Kai Li and Dale J. Poirier, Relationship Between Maternal Behavior During Pregnancy, Birth Outcome, and Early Childhood Development: An Exploratory Study, September 2003

1031 Ivar Ekeland, James J. Heckman, and Lars Nesheim, Identifcation and Estimation of Hedonic Models, September 2003

1032 Kjetil Bjorvatn and Alexander W. Cappelen, Decentralization and the Fate of Minorities, September 2003

1033 Lars-Erik Borge and Jørn Rattsø, The Relationships Between Costs and User Charges: The Case of a Norwegian Utility Service, September 2003

1034 Maureen Were and Nancy N. Nafula, An Assessment of the Impact of HIV/AIDS on Economic Growth: The Case of Kenya, September 2003

1035 A. Lans Bovenberg, Tax Policy and Labor Market Performance, September 2003

1036 Peter Birch Sørensen, Neutral Taxation of Shareholder Income: A Norwegian Tax Reform Proposal, September 2003

1037 Roberta Dessi and Sheilagh Ogilvie, Social Capital and Collusion: The Case of Merchant Guilds, September 2003

1038 Alessandra Casarico and Carlo Devillanova, Capital-skill Complementarity and the Redistributive Effects of Social Security Reform, September 2003

1039 Assaf Razin and Efraim Sadka, Privatizing Social Security Under Balanced-Budget Constraints: A Political-Economy Approach, September 2003

1040 Michele Moretto, Paolo M. Panteghini, and Carlo Scarpa, Investment Size and Firm's Value under Profit Sharing Regulation, September 2003

1041 A. Lans Bovenberg and Peter Birch Sørensen, Improving the Equity-Efficiency Tradeoff: Mandatory Savings Accounts for Social Insurance, September 2003

1042 Bas van Aarle, Harry Garretsen, and Florence Huart, Transatlantic Monetary and Fiscal Policy Interaction, September 2003 
1043 Jerome L. Stein, Stochastic Optimal Control Modeling of Debt Crises, September 2003

1044 Thomas Stratmann, Tainted Money? Contribution Limits and the Effectiveness of Campaign Spending, September 2003

1045 Marianna Grimaldi and Paul De Grauwe, Bubbling and Crashing Exchange Rates, September 2003

1046 Assar Lindbeck and Dennis J. Snower, The Firm as a Pool of Factor Complementarities, September 2003

1047 Volker Grossmann, Firm Size and Diversification: Asymmetric Multiproduct Firms under Cournot Competition, September 2003

1048 Dan Anderberg, Insiders, Outsiders, and the Underground Economy, October 2003

1049 Jose Apesteguia, Steffen Huck and Jörg Oechssler, Imitation - Theory and Experimental Evidence, October 2003

1050 G. Abío, G. Mahieu and C. Patxot, On the Optimality of PAYG Pension Systems in an Endogenous Fertility Setting, October 2003

1051 Carlos Fonseca Marinheiro, Output Smoothing in EMU and OECD: Can We Forego Government Contribution? A Risk Sharing Approach, October 2003

1052 Olivier Bargain and Nicolas Moreau, Is the Collective Model of Labor Supply Useful for Tax Policy Analysis? A Simulation Exercise, October 2003

1053 Michael Artis, Is there a European Business Cycle?, October 2003

1054 Martin R. West and Ludger Wößmann, Which School Systems Sort Weaker Students into Smaller Classes? International Evidence, October 2003

1055 Annette Alstadsaeter, Income Tax, Consumption Value of Education, and the Choice of Educational Type, October 2003

1056 Ansgar Belke and Ralph Setzer, Exchange Rate Volatility and Employment Growth: Empirical Evidence from the CEE Economies, October 2003

1057 Carsten Hefeker, Structural Reforms and the Enlargement of Monetary Union, October 2003 